\title{
Rules for review of writing methodology
}

\section{Odina BAKHRIDINOVA ${ }^{1}$, Qahramon HAKIMOV²}

State Institute of Foreign Languages

\begin{tabular}{l} 
ARTICLE INFO \\
\hline Article history: \\
Received May 2021 \\
Received in revised form \\
20 May 2021 \\
Accepted 15 June 2021 \\
Available online \\
15 July 2021
\end{tabular}

\section{Keywords:}

review,

feedback,

rules of review,

research,

writing.

\begin{abstract}
Based on the description of the rules of the review of writing methodology, this article proposes some basic methods to be implemented in prose writing. It is highly recommended to organize an effective review through the above rules.
\end{abstract}

2181-1415/C) 2021 in Science LLC.

This is an open access article under the Attribution 4.0 International (CC BY 4.0) license (https://creativecommons.org/licenses/by/4.0/deed.ru)

\section{Yozish mahorati metodikasini sharh qilish qoidalari}

\section{Kalit so'zlar:}

Ko'rib chiqish,

fikr-mulohaza,

ko'rib chiqish qoidalari,

tadqiqot,

yozish mahorati.

\section{ANNOTATSIYA}

Ushbu maqola yozuv metodologiyasini ko'rib chiqish qoidalarining tavsifiga asoslanib, nasrda yozishda qo'llaniladigan ba'zi bir asosiy usullarni taklif etilgan. Yuqoridagi qoidalar orqali samarali tekshirishni tashkil qilish tavsiya etilgan.

\section{Правила интерпретации техники навыков письма}

\footnotetext{
Ключевые слова:

рецензия,

отзывы,

правила рецензирования, исследование,

навыки письменности.
}

\begin{abstract}
АННОТАЦИЯ
В данной статье на основе описания правил рецензирования методологии написания предлагается несколько основных методов, которые будут реализованы в написании прозы. Настоятельно рекомендуется организовать эффективную проверку в соответствии с приведенными выше правилами.
\end{abstract}

\footnotetext{
${ }^{1}$ Student, Samarkand State Institute of Foreign Languages. Samarkand, Uzbekistan.

E-mail: odinabaxriddinova@gmail.com.

${ }^{2}$ Lecturer, Samarkand State Institute of Foreign Languages, Samarkand, Uzbekistan.
} 


\section{INTRODUCTION}

A systematic methodological review of the literature, including "grey" literature, such as reports, doctoral dissertations, and book chapters, was conducted to test existing guidance and recommended practices for conducting and presenting meta-ethnographic reports in any discipline.

\section{SEARCH STRATEGY}

We first conduct a comprehensive search of the database and then do a comprehensive search to discover published and unpublished research in any language. These searches are iterative and evolutionary because the review has progressed and because it is intended to provide us with advice and guidance on conducting and reporting meta-ethnography, rather than answering a strictly defined research question. Literature reviews are in high demand in most scientific fields. Its demand comes from the increasing production of scientific publications [1]. For example, compared to 1991, the number of articles on malaria, obesity and biodiversity indexed by Web of Science in 2008 increased 3, 8 and 40 times, respectively [2]. Given the pile of articles, scientists cannot be expected to scrutinize every new article related to their interests [3]. Therefore, it is desirable and necessary to rely on regular summaries of recent literature. Although the recognition of scientists mainly comes from primary research, timely literature reviews can bring new comprehensive insights and are often widely read [4]. However, in order for these abstracts to be useful, they must be professionally compiled [5].

\section{METHODS}

When starting from scratch, searching for the literature can take a lot of work. That is why researchers who dedicate their careers to a research problem are in the perfect position to review the literature. Since most graduate students begin their projects by outlining the research questions that have been completed [6], some graduate schools now offer literature review courses. However, most scientists may not have considered in detail how to conduct a literature review. Literature review requires the ability to handle multiple tasks, from finding and evaluating relevant materials to synthesizing information from various sources, from critical thinking to paraphrasing, evaluation, and citation skills [7]. In this article, I shared ten simple rules that I learned as a doctoral and postdoc in approximately 25 literature reviews. Ideas and insights also come from discussions with co-authors and colleagues, as well as comments from reviewers and editors.

How to choose a review topic? There are so many questions in contemporary science that you could spend a lifetime attending lectures and reading literature wondering what to review. For one thing, if it takes you a few years to make up your mind, other people may have the same idea during this period. On the other hand, only well thought out topics can guide an excellent literature review [8]. The topic must at least be:

- Very interesting to you (ideally, you should find some recent articles related to your work and decide to make a critical summary),

- A key aspect of the field (many readers will be curious about the review, and there will be enough material to write it), and

- A well-defined topic (otherwise it might contain thousands of posts, which might make comments useless). 
Ideas for possible comments can come from articles that provide a list of key research questions to be answered [9], or from accidental moments in out-of-line reading and discussions. In addition to choosing a topic, you must also choose your target audience. In many cases, topics (for example, Web services in computational biology) automatically define the audience (for example, computational biologists), but the same topic may also arouse interest in neighboring fields (for example, computer science, biology, etc.) . .

After having chosen your topic and audience, start by checking the literature and downloading relevant papers. Five pieces of advice here:

- keep track of the search items you use (so that your search can be replicated [10],

- keep a list of papers whose pdfs you cannot access immediately (so as to retrieve them later with alternative strategies),

- use a paper management system

- define early in the process some criteria for exclusion of irrelevant papers (these criteria can then be described in the review to help define its scope), and

- do not just look for research papers in the area you wish to review, but also seek previous reviews.

- discussing in your review the approaches, limitations, and conclusions of past reviews,

- trying to find a new angle that has not been covered adequately in the previous reviews, and

- incorporating new material that has inevitably accumulated since their appearance.

When searching for related articles and reviews in the literature, the usual rules apply:

- Completely,

- Use different keywords and database sources (such as DBLP, Google Scholar, ISI Proceedings, JSTOR Search, Medline, Scopus, Web of Science) and

- See who has cited relevant previous book chapters and articles.

\section{RESULTS AND DISCUSSION}

If you read the article first and then start to write comments, you will need a very good memory to remember who wrote what, and their impressions and associations when reading each article. My suggestion is to write interesting data snippets, ideas on how to organize comments and thoughts on the content of the writing while reading. This way, when you read the selected literature, you may have already obtained a draft of the review. Of course, this draft still requires a lot of rewriting, reorganization, and rethinking to get a text with coherent arguments [11], but you have avoided the danger of viewing blank documents. If you are temporarily copying verbatim from a document, be careful to use quotes when taking notes. Therefore, it is recommended to restate these quotes in your own words in the final draft. When writing references that are already at this stage, be careful to avoid false attributions. Using the reference software in the early stages of your efforts will save you time.

After taking notes while reading the literature, you may have a rough idea of the number of fabrics available for review. This may be a good time to decide whether to travel for a minimum or full review. In recent years, some magazines prefer to publish fairly short professional reviews and limit the number of words and citations. The short comment is not necessarily a minor revision: it should attract more attention from busy readers, although due to space limitations, it will inevitably simplify some issues and omit some 
related materials. The advantage of a full review is that it can hide the complexity of a particular scientific development more freely and well, but then readers may not have time to focus on the main monograph and leave it in the pile of important "read" articles.

There may be continuity between mini reviews and full reviews. The same argument applies to the dichotomy of descriptive and comprehensive reviews. Descriptive reviews focus on the methodology, findings, and explanations of each research reviewed, while comprehensive reviews try to find common ideas and concepts from the materials reviewed [12]. There is a similar distinction between narrative reviews and systematic reviews: Although narrative reviews are qualitative, systematic reviews try to test hypotheses based on published evidence, which is collected using predefined protocols to reduce bias [13], [14]. When systematic reviews analyze quantitative results in a quantitative manner, they become meta-analysis. The choice between different types of reviews must be made on a case-by-case basis, not only on the nature of the material found and the preferences of the target journal, but also on the time available to write reviews and numbers [15].

\section{CONCLUSION}

Whether your plan is to write a short review or a complete review, staying focused 16,17 are good suggestions. Including material in order to include material can easily lead to comments trying to do too many things at once. The need to maintain focused reviews can be problematic for interdisciplinary reviews, with the goal of bridging the gap between fields [18]. For example, if you are writing a review on how to use epidemiological methods to simulate the spread of ideas, you may tend to include materials from the two main areas of epidemiology and cultural communication research. This may be necessary to some extent, but in this case, the focused review will only deal with the interface between epidemiology and the spread of ideas in detail. Although the focus is an important feature of a successful review, this requirement must be balanced with the need to make the review relevant to a broad audience. You can circle this box to discuss the broader impact of the revised theme on other disciplines.

\section{REFERENCES:}

1. Rapple C (2011) The role of the critical review article in alleviating information overload. Annual Reviews White Paper. Available: http://www.annualreviews.org /userimages/ContentEditor/1300384004941/Annual_Reviews_WhitePaper_Web_2011. pdf. Accessed May 2013.

2. Pautasso M. (2010) Worsening file-drawer problem in the abstracts of natural, medical and social science databases. Scientometrics 85. - PP. 193-202.

3. Erren T.C., Cullen P, Erren M. (2009) How to surf today's information tsunami: on the craft of effective reading. Med Hypotheses 73. - PP. 278-279

4. Hampton S.E., Parker J.N. (2011) Collaboration and productivity in scientific synthesis. Bioscience 61. - PP. 900-910.

5. Ketcham C.M., Crawford J.M. (2007) The impact of review articles. Lab Invest 87. - PP. 1174-1185.

6. Boote D.N., Beile P. (2005) Scholars before researchers: on the centrality of the dissertation literature review in research preparation. Educ Res 34. - PP. 3-15. 
7. Budgen D., Brereton P. (2006) Performing systematic literature reviews in software engineering. Proc 28th Int Conf Software Engineering, ACM New York, NY, USA, PP. 1051-1052. DOI: https://doi.org/10.1145/1134285.1134500.

8. Maier H.R. (2013) What constitutes a good literature review and why does its quality matter? Environ Model Softw 43. - PP. 3-4.

9. Sutherland W.J., Fleishman E., Mascia M.B., Pretty J., Rudd M.A. (2011) Methods for collaboratively identifying research priorities and emerging issues in science and policy. Methods Ecol Evol 2. - PP. 238-247.

10. Maggio L.A., Tannery N.H., Kanter S.L. (2011) Reproducibility of literature search reporting in medical education reviews. Acad Med 86. - PP. 1049-1054.

11. Torraco R.J. (2005) Writing integrative literature reviews: guidelines and examples. Human Res Develop Rev 4. - PP. 356-367.

12. Khoo C.S.G, Na J.C., Jaidka K. (2011) Analysis of the macro-level discourse structure of literature reviews. Online Info Rev 35. - PP. 255-271.

13. Rosenfeld R.M. (1996) How to systematically review the medical literature. Otolaryngol Head Neck Surg 115. - PP. 53-63.

14. Cook D.A., West C.P. (2012) Conducting systematic reviews in medical education: a stepwise approach. Med Educ 46. - PP. 943-952.

15. Dijkers M (2009) The Task Force on Systematic Reviews and Guidelines (2009) The value of "traditional" reviews in the era of systematic reviewing. Am J. Phys Med Rehabil 88. - PP. 423-430.

16. Eco U (1977) Come si fa una tesi di laurea. Milan: Bompiani.

17. Hart C (1998) Doing a literature review: releasing the social science research imagination. London: SAGE. 